\title{
Study of the Cardiac Alterations in HIV-Infected Children Consequent to the Antiretroviral Therapy. Prospective Study of 47 Cases
}

\author{
Gesmar Volga Haddad Herdy, Carlos Alberto M. Pinto, Vania Gloria S. Lopes, Raquel P. Ribeiro, \\ Ivete Martins Gomes, Hsu Y. Tchou, Renata Melo, Bedros Kurdian, Plínio de Assis Tavares Jr.
}

Niterói, RJ - Brazil

Objective - Detect of cardiac alterations in children with AIDS and compare their evolution with the administration of only one anti-retroviral and the recent cases who received drugs in combination.

Methods - We prospectively studied 47 children in 3 groups: group 1, 20 cases treated only with zidovudine; group 2, 10 patients treated initially with zidovudine and later with a combination of drugs and in group 3, 17 patients, who receiced two or three since the beginning. In all patients it was done chest X-ray, EKG and echocardiography every 6 months and after death complete pathological study.

Results - Among the 45 patients cases $26(57 \%)$ were index cases. Malnutrition, diarrhea tachycardia, signs of congestive heart failure, pericardial effusion, abnormal ventricular repolarization and arrhythmias were more frequent in group 1. Echocardiographic abnormalities were present in $10(50 \%)$ children of group 1. They were less frequent in the others two groups. In regard to the outcome in group 1, two patients had worsening of sings of cardiomyopaty and 4 died. Cardiac dysfunction in all cases of group 2 and 3 improved with the medication.

Conclusion - The children who received combination and their cardiac alterations had more favorable outcome than those who received only one drug.

Keywords: heart, children, AIDS

Hospital Universitário Antônio Pedro - UFF

Mailing address: Gesmar Volga Haddad Herdy - Travessa Antonio Pedro, 10/301

- 24230-030 - Niterói, RJ, Brazil - E-mail: gesmar@web4u.com.br

English version by Stela Maris C. e Gandour
Currently, approximately $90 \%$ of the children with acquired immunodeficiency syndrome (AIDS) notified in Brazil were infected via vertical transmission ${ }^{1}$.

At our institution, we have been carrying out a prospective study of the cardiac alterations in children infected with $\mathrm{HIV}^{2}$. Thanks to the protocols for preventing vertical transmission adopted in our country, we have observed an up to $70 \%$ reduction in infected children ${ }^{3-5}$. A prospective multicenter study showed that in children with changes in heart size and heart function, a reduction in survival was observed independent of other variables ${ }^{6}$. Our study aimed at prospectively assessing the cardiac alterations in these patients, following their evolution with the use of the medication, including the antiretroviral agents, and at comparing data obtained in children receiving new combinations of medication.

\section{Methods}

We prospectively studied 47 children followed up at the Hospital Universitário Antônio Pedro, in the city of Niterói, from January 1993 to December 2000. They were divided into 3 groups as follows: group 1 -comprising the first 20 patients, whose ages ranged from 6 months to 12 years (median of 36 months), treated only with the antiretroviral agent zidovudine; group 2 - comprising 10 patients with ages ranging from 4 months to 7 years (median of 30 months) diagnosed before December 1995, who initially received only zidovudine and then a combination of that drug and another with the same finality; group 3-comprising 17 children aged from 1 to 10 years (median of 2 years), who were the most recent patients, diagnosed after January 1996, and who received a combination of 2 or 3 antiretroviral drugs since the beginning. The criterion for the use of these drugs followed the recommendations of the Ministry of Health ${ }^{7}$. Replacement of the drugs was required on several occasions due to intolerance or lack of appropriate response. The most frequently used 
drugs in these children were as follows: 1) nucleoside analog reverse transcriptase inhibitors: zidovudine (AZT), didanosine (DDI), stavudine (D4T), lamivudine (3TC); 2) nonnucleoside analog reverse transcriptase inhibitors, mainly nevirapine (NVP); and 3) protease inhibitors: nelfinavir(NFV), ritonavir(RTV), indinavir(IDV) ${ }^{7}$.

The laboratory tests for diagnosing AIDS were as follows: ELISA - VIDAS system - Biolab, which uses the enzyme-linked fluorescent immunoassay (ELFA) for detecting HIV 1 and 2; and the AXSYM-Abbot system, which is a microparticle immunoassay technique that uses recombinant antigens derived from 3 proteins of HIV 1 and 2. When positive twice, the Western Blot method was used for confirmation.

We used the revised classification system of human immunodeficiency virus infection in children of the Centers for Disease Control and Prevention (CDC) in Atlanta, $1994^{8}$, for assessing clinical and immunologic signs.

The protocol for semestral cardiological evaluation comprised a clinical examination performed by the pediatric cardiology staff, chest radiographies, echocardiography, and Doppler two-dimensional echocardiography (ESAOTE 5000 device) every 6 months. These procedures were repeated due to infectious intercurrences or worsening of the cardiac symptoms. Thickness of the walls and cavitary diameters were measured, and ventricular mass, and ejection and shortening fractions were calculated ${ }^{9}$. An ejection fraction $>60 \%$ and a systolic shortening of the left ventricular diameter $>30 \%$ were considered normal. An autopsy was performed in all patients who died.

The patients in groups 2 and 3 also underwent measurement of the viral load and CD4 and CD8 lymphocyte count according to the NASBA-NUCLISENS method, through an agreement with the Miguelote Vianna Laboratory of the State Secretariat of Health.

Follow-up in the different groups was as follows (in months): group 1 - 30, group 2 - 72, and group 3 - 36 .

The statistical analysis was performed with the nonparametric chi-square test.

\section{Results}

Of the 20 children in group 1,19 were infected via vertical transmission and only 1 patient via blood transfusion. In that group, $13(65 \%)$ were considered index cases. In group 2, all the 10 patients acquired the infection from the mother, and $3(30 \%)$ were index cases. In group 3, of the 17 children, only 1 acquired HIV via transfusion, and $10(60 \%)$ were index cases. Of the 45 children who received the virus via vertical transmission, $26(57 \%)$ were index cases. The most common clinical alterations are shown in table I. The first 5 signs or symptoms prevailed in the 3 groups: undernutrition, crises of diarrhea, repeated pneumopathies, anemia, and hepatosplenomegaly. Undernutrition and the crises of diarrhea were more frequent in group 1 than in the other groups with a statistically significant difference $(\mathrm{p}<0.01$ and $\mathrm{p}<0.05$, respectively).

\begin{tabular}{|c|c|c|c|c|c|c|}
\hline \multicolumn{7}{|c|}{ Table I - Clinical signs and symptoms } \\
\hline \multirow[t]{2}{*}{ Signs/symptoms } & \multicolumn{2}{|c|}{$\begin{array}{l}\text { Group 1 } \\
(\mathrm{n}=20)\end{array}$} & \multicolumn{2}{|c|}{$\begin{array}{c}\text { Group } 2 \\
(n=10)\end{array}$} & \multicolumn{2}{|c|}{$\begin{array}{c}\text { Group } 3 \\
(\mathrm{n}=17)\end{array}$} \\
\hline & $\begin{array}{c}\mathrm{N}^{\circ} \\
\text { cases }\end{array}$ & $\%$ & $\begin{array}{c}\mathrm{N}^{\circ} \\
\text { cases }\end{array}$ & $\%$ & $\begin{array}{c}\mathrm{N}^{\circ} \\
\text { cases }\end{array}$ & $\%$ \\
\hline Undernutrition & 16 & 80 & 3 & 30 & 7 & 41 \\
\hline Crises of diarrhea & 14 & 70 & 3 & 30 & 6 & 35 \\
\hline Repeated pneumopathies & 14 & 70 & 4 & 40 & 10 & 60 \\
\hline Anemia & 10 & 50 & 3 & 30 & 4 & 23 \\
\hline Hepatospleno-megaly & 9 & 45 & 4 & 40 & 6 & 35 \\
\hline Adenomegaly & 8 & 40 & 4 & 40 & 6 & 35 \\
\hline Psychomotor retardation & 8 & 40 & 2 & 20 & 3 & 18 \\
\hline Candidiasis (skin and mucosas) & 8 & 40 & 3 & 30 & 4 & 23 \\
\hline Enlarged parotid glands & 7 & 35 & 2 & 20 & 3 & 18 \\
\hline Frequent otites & 6 & 30 & 2 & 20 & 5 & 30 \\
\hline Dermatitis/impetigo/abscesses & 3 & 15 & 2 & 20 & 3 & 18 \\
\hline Herpes zoster & 1 & 5 & 1 & 10 & 1 & 6 \\
\hline
\end{tabular}

The HIV viral load analysis prior to and after the antiretroviral treatment during the follow-up of the children was useful for guiding the change in medication.

The antiretroviral agents were used as follows. In group 1, all the 20 patients received only AZT. In group 2 , all the 10 patients initially received AZT, DDI being added after 6 to 8 months. Of these patients, $6(60 \%)$ failed to respond, and $2(20 \%)$ patients received the combination of D4T and 3TC, with which they remained during a mean period of 48 months. Two other (20\%) patients received the combination of D4T, 3TC, and ritonavir during a mean follow-up of 52 months. Two children (20\%) received AZT, DDI and nevirapine for a mean observation period of 50 months. The 17 patients in group 3 received from the beginning a combination of medications as follows: $8(47 \%)$ patients received AZT, 3TC, and nelfinavir, and the other $9(53 \%)$ received D4T, DDI, and nelfinavir (follow-up ranging from 18 to 24 months). The control of opportunistic infections with immunoglobulins was irregularly performed in only 8 patients in group 1 due to a failure in acquiring the medication. It was regularly performed in 7 children in group 2 and in 9 children in group 3 , and was indicated when hypogammaglobulinemia was detected on laboratory tests. Ganciclovir, indicated when cytomegalovirus infection was confirmed, was administered to 3 patients in group 1 , to 2 patients in group 2 , and to 1 patient in group 3 .

On cardiovascular examination, the following findings were frequent in the 3 groups: tachycardia at rest, systolic murmur in the left sternal margin, propulsive ictus, heart failure, increased cardiothoracic index, and muffled heart sounds when moderate to intense pericardial effusion occurred (tab. II). Comparing these findings, a significant difference between groups 1 and 3 was observed in regard to tachycardia at rest $(\mathrm{p}<0.01)$. The other data did not show the same importance.

The most common electrocardiographic findings in all groups were alterations in ventricular repolarization asso- 


\begin{tabular}{|c|c|c|c|c|c|c|}
\hline \multicolumn{7}{|c|}{ Table II - Cardiac signs and symptoms } \\
\hline \multirow[t]{2}{*}{ Signs/symptoms } & \multicolumn{2}{|c|}{$\begin{array}{c}\text { Group } 1 \\
(n=20)\end{array}$} & \multicolumn{2}{|c|}{$\begin{array}{c}\text { Group } 2 \\
(\mathrm{n}-10)\end{array}$} & \multicolumn{2}{|c|}{$\begin{array}{c}\text { Group } 3 \\
(\mathrm{n}=17)\end{array}$} \\
\hline & $\begin{array}{c}\mathrm{N}^{\circ} \\
\text { cases }\end{array}$ & $\%$ & $\begin{array}{c}\mathrm{N}^{\circ} \\
\text { cases }\end{array}$ & $\%$ & $\begin{array}{c}\mathrm{N}^{\circ} \\
\text { cases }\end{array}$ & $\%$ \\
\hline Tachycardia at rest & 10 & 50 & 6 & 60 & 4 & 23 \\
\hline Systolic murmur in the LSM & 6 & 30 & 3 & 30 & 4 & 23 \\
\hline Signs of CHF, NYHA III and IV & 5 & 25 & 2 & 20 & 1 & 6 \\
\hline Increased cardiac index on $\mathrm{RX}$ & 4 & 20 & 3 & 30 & 2 & 12 \\
\hline Propulsive ictus & 3 & 15 & 1 & 10 & 1 & 6 \\
\hline Muffled heart sounds & 3 & 15 & 1 & 10 & 1 & 6 \\
\hline Mitral systolic murmur & 1 & 5 & - & - & 1 & 6 \\
\hline Mitral diastolic murmur & 1 & 5 & - & - & - & - \\
\hline Pericardial friction & 1 & 5 & 1 & 5 & - & - \\
\hline
\end{tabular}

ciated or not with sinus tachycardia. In group 1, these alterations were more frequent (tab. III), and a statistically significant difference was observed between groups 1 and 3 in regard to repolarization alterations and sinus tachycardia with left ventricular overload $(\mathrm{p}<0.05)$. In group 3 , normal echocardiograms were significantly more common than in the other groups $(\mathrm{p}<0.05)$.

An abnormal echocardiogram was found in $50 \%$ of the patients in group 1. Left ventricular systolic dysfunction was the most frequent abnormality in all groups, and, in several patients, it was associated with pericardial effusion or cavitary dilation (tab. IV). The 10 patients in group 1 with systolic dysfunction had ejection fractions between 26 and $40 \%$ (mean of $34.1 \%$; SD of 5.1). The 4 patients in group 2 with abnormalities had an ejection fraction ranging from 27 to $41 \%$ (mean of $33.7 \%$; SD of 5.06), and the 4 patients in group 3 with abnormalities had an ejection fraction ranging from 31 to $48 \%$ (mean of $34 \%$; SD of 2.94). The comparison between groups 1 and 3 showed a statistically significant difference in regard to systolic dysfunction associated with an increase in the diameter of the left cavities, more frequent in group $1(\mathrm{p}<0.05)$. In some patients, the parameters of diastolic function assessed were normal.

\begin{tabular}{|c|c|c|c|c|c|c|}
\hline \multicolumn{7}{|c|}{ Table III - Electrocardiographic alterations } \\
\hline \multirow[t]{2}{*}{ Result } & \multicolumn{2}{|c|}{$\begin{array}{l}\text { Group } 1 \\
(\mathrm{n}=20)\end{array}$} & \multicolumn{2}{|c|}{$\begin{array}{l}\text { Group } 2 \\
(\mathrm{n}=10)\end{array}$} & \multicolumn{2}{|c|}{$\begin{array}{c}\text { Group } 3 \\
(n=17)\end{array}$} \\
\hline & $\begin{array}{l}\mathrm{N}^{\circ} \\
\text { cases }\end{array}$ & $\%$ & $\begin{array}{c}\mathrm{N}^{\circ} \\
\text { cases }\end{array}$ & $\%$ & $\begin{array}{c}\mathrm{N}^{\circ} \\
\text { cases }\end{array}$ & $\%$ \\
\hline Normal & 7 & 35 & 6 & 60 & 15 & 88 \\
\hline $\begin{array}{l}\text { Ventr. repol. } \\
\text { alteration + tachycardia }\end{array}$ & 5 & 25 & 2 & 20 & 1 & 6 \\
\hline $\begin{array}{l}\text { Sinus tachycardia } \\
+ \text { LV overload }\end{array}$ & 4 & 20 & 1 & 10 & - & - \\
\hline $\begin{array}{l}\text { Sinus tachycardia } \\
\text { Supraventricula }\end{array}$ & 1 & 5 & - & - & - & - \\
\hline Supraventricular extrasystoles & 1 & 5 & 1 & 10 & 1 & 6 \\
\hline Nodal rhythm & 1 & 5 & - & - & & \\
\hline Ventricular extrasystoles & 1 & 5 & - & - & - & - \\
\hline
\end{tabular}

\begin{tabular}{|c|c|c|c|c|c|c|}
\hline \multicolumn{7}{|c|}{ Table IV - Echocardiographic results } \\
\hline \multirow[t]{2}{*}{ Results } & \multicolumn{2}{|c|}{$\begin{array}{l}\text { Group } 1 \\
(\mathrm{n}=20)\end{array}$} & \multicolumn{2}{|c|}{$\begin{array}{c}\text { Group } 2 \\
(\mathrm{n}=10)\end{array}$} & \multicolumn{2}{|c|}{$\begin{array}{c}\text { Group } 3 \\
(\mathrm{n}=17)\end{array}$} \\
\hline & $\begin{array}{c}\mathrm{N}^{\circ} \\
\text { cases }\end{array}$ & $\%$ & $\begin{array}{c}\mathrm{N}^{\circ} \\
\text { cases }\end{array}$ & $\%$ & $\begin{array}{c}\mathrm{N}^{\circ} \\
\text { cases }\end{array}$ & $\%$ \\
\hline Normal & 10 & 50 & 6 & 60 & 13 & 76 \\
\hline $\begin{array}{l}\text { Moderate dysfunction } \\
\text { and LV dilation }\end{array}$ & 6 & 30 & 2 & 20 & 2 & 12 \\
\hline $\begin{array}{l}\text { Systolic dysfunction } \\
\text { and moderate effusion } \\
\text { Pericardial effusion }\end{array}$ & 2 & 10 & 1 & 10 & 1 & 6 \\
\hline $\begin{array}{l}\text { Hypertrophy of the IVS and LVPW, } \\
\downarrow \text { in relaxation }\end{array}$ & 1 & 5 & 0 & 0 & 0 & 0 \\
\hline $\begin{array}{l}\text { Systolic dysfunction, mild effusion, } \\
\text { and hypertrophy of the IVS and LVPV }\end{array}$ & $\mathrm{W}^{1}$ & 5 & 1 & 10 & 1 & 6 \\
\hline $\begin{array}{l}\downarrow \text { - reduction; LV- left ventricle; IVS- } \\
\text { ventricular posterior wall. }\end{array}$ & - in & t & ar se & & $\mathrm{P}$ & \\
\hline
\end{tabular}

The treatment of congestive heart failure was the same in all cases: diuretics, captopril, and digitalis. Patients with significant pericardial effusion underwent diagnostic puncture and surgical drainage, when necessary.

Improvement in the clinical signs of congestive heart failure were observed in 4 patients in group 1 , which was confirmed by the elevation in the ventricular function parameters and by the electrocardiographic alterations. Three $(15 \%)$ children in group 1 and $1(10 \%)$ child in group 2 remained with sinus tachycardia associated with an alteration in ventricular repolarization. One patient in group 3 remained with supraventricular extrasystole. The subsequent echocardiographic findings in patients in group 1 were as follows: of the 10 patients with systolic dysfunction, 3 (30\%) had a significant improvement in the parameters, and $1(10 \%)$ had them normalized. The evolution was unfavorable in 6 patients; clinical and echocardiographic worsening was observed in $2(20 \%)$ patients who died. The myocardial histological findings in these 2 patients showed only alterations compatible with metabolic disorder. Two (20\%) children died due to myocarditis, 1 caused by Toxoplasma gondii, and the other by disseminated cytomegalovirus infection (CMV). The echocardiogram in both children showed thickening of the septum and the left ventricular posterior wall. Two other children died due to other causes: 1 had pneumonia caused by Pneumocystis carinii and another had sepsis caused by Candida. In group 2, the $4(100 \%)$ patients normalized their ventricular dysfunction, which also happened with the patients in group 3 (tab. V). One child in group 2 died, but an autopsy was not performed. All group 3 children continue on ambulatory followup; none of them have died so far.

\section{Discussion}

Vertical transmission was observed in $95 \%$ of our patients, and this is a frequent finding in most case series ${ }^{1,10,11}$. The mother-child HIV transmission rate, when no prevention occurs during pregnancy, ranges from 20 to $40 \%$, and, 


\begin{tabular}{|c|c|c|c|c|c|c|c|c|}
\hline \multirow{2}{*}{\multicolumn{2}{|c|}{$\begin{array}{c}\text { Group } 1 \\
\text { Moderate systolic dysfunctio } \quad(\mathrm{N}=10)\end{array}$}} & \multirow{2}{*}{\multicolumn{4}{|c|}{$\begin{array}{c}\text { Group } 2 \\
\text { Systolic dysfunction }(\mathrm{N}=4)\end{array}$}} & \multirow{2}{*}{\multicolumn{3}{|c|}{$\begin{array}{c}\text { Group } 3 \\
\text { Systolic dysfunction }(\mathrm{N}=4)\end{array}$}} \\
\hline & & & & & & & & \\
\hline Improvement & 4 & $40 \%$ & Improvement & 4 & $100 \%$ & Improvement & 4 & $100 \%$ \\
\hline Clinical and echocardiographic worsening & 2 & $20 \%$ & 0 & 0 & & 0 & 0 & \\
\hline Death due to myocarditis & 2 & $20 \%$ & 0 & 0 & & 0 & 0 & \\
\hline Death due to pneumonia and sepsis & 2 & $20 \%$ & 0 & 0 & & 0 & 0 & \\
\hline
\end{tabular}

with the correct use of AZT, it ranges from 2 to $5 \%$, 5 . In this study and in the one previously reported ${ }^{2}$, several children were index cases, and, therefore, did not receive protection.

In regard to clinical manifestations, the patients receiving only AZT (group 1) had more complications or opportunistic infections than those receiving the combined therapy. The combination of drugs is known to be more effective in the control of viral replication ${ }^{13,14}$. Children in group 1 also had more cardiac alterations. Twenty-five per cent of them had signs of congestive heart failure during hospitalization. Several factors may have accounted for congestive heart failure. The human immunodeficiency virus itself may be isolated in the myocardium ${ }^{15}$. The drugs used in the treatment, such as AZT and DDI, are considered cardiotoxic, although worsening of cardiac symptoms have not been reported in children after their use so far ${ }^{16,17}$. Undernutrition, which was more frequent in group 1, might have contributed to the greater incidence of echocardiographic alterations, because poor absorption, electrolyte imbalance, and deficiency in oligoelements are directly or indirectly associated with cardiomyopathy ${ }^{17-19}$. Opportunistic infections, mainly CMV, and those caused by Toxoplasma gondii, Pneumocystis carinii, and Mycobacterium, may directly or indirectly account for the cardiac manifestations ${ }^{20,21}$. Several studies reported that severe infections may lead to the release of cytokines, which reduce cardiac work and ejection fraction, improving congestive heart failure ${ }^{22,23}$. Some authors showed that cytokines, such as the interleukins (IL-1, IL-6, and IL-10) andTNF- $\alpha$, have a negative inotropic effect, altering the homeostasis of intracellular calcium and inducing the production of nitric oxide, which depresses cardiac function and promotes apoptosis ${ }^{24,25}$.

The electrocardiographic findings are unspecific; they may be found in myocarditis or dilated cardiomyopathy of other causes, and comprise alterations in ST segment and T wave ${ }^{19,20}$. In our patients, the echocardiogram provided important information for the correlation of the clinical data of congestive heart failure and its outcome. The findings of left ventricular dysfunction with dilation of the cavities, usually associated with pericardial effusion, are also the same as previously reported ${ }^{2,6,17}$. In group $1,50 \%$ of the patients had important alterations, and only $40 \%$ improved with treatment (drugs for congestive heart failure and those specific for infections). In the other groups, a 100\% improvement was observed after the same treatment; the difference was the use of antiretroviral agents and the better approach to the opportunistic infections. Some patients in group 1 died due to myocarditis or worsening of the clinical and echocardiographic findings. Lipshultz et al ${ }^{6}$ studied 193 children infected with HIV and reported that shortening fraction and thickening of the wall are the 2 parameters considered risk factors for mortality independent of the other clinical variables and CD4 count. Two of our patients with fatal myocarditis also had thickening of the left ventricular walls.

Pericardial effusion, including that in combination with cardiac tamponade, was a frequent finding in our study, occurring in approximately $22 \%$ of our patients ${ }^{17}$. It may be related to opportunistic infections, but sometimes its cause is unknown. Effusion is part of the diffuse serous process involving the peritoneum and pleura, due to capillary overflow consequent to an increase in cytokines, mainly TNF- $\alpha{ }^{26}$.

The drug regimens of inhibitors of viral replication used abided by the recommendations of the Ministry of Health ${ }^{7}$. The first drug approved for children, AZT, was used for the patients in group 1. In the 1990s, DDI was also approved for pediatric use, and the 2 drugs were combined for group 2 patients, as recommended to reduce resistan$\mathrm{ce}^{27}$. The most recent patients received triple therapy, whose indication is guided by clinical and laboratory findings, using the classification of the CDC (1994) for children in the A3, B2, B3, C1, C2, and C3 categories ${ }^{7}$. Triple therapy has been much more effective in controlling the disease; it increases the percentage of CD4 lymphocytes and reduces the HIV viral load ${ }^{28,29}$.

Children with hypogammaglobulinemia were treated with human immunoglobulin, except some in group 1 , whose treatment was not as regular as that in the other 2 groups, because of failure in acquiring the medication. In the beginning of the 1990s, passive immunization with immunoglobulin was reported to reduce HIV viral load in the blood stream to levels that could not be detected by the PCR technique $^{30}$. Immunoglobulins monthly administered also lead to an improvement in ventricular dysfunction, decreased wall thickening, and reduced the peak of left ventricular wall stress. The apparent efficacy of this medication may be attributed to inhibition of autoantibodies, such as anti-a myosin, whose prevalence is increased in patients with dilated cardiomyopathy due to competition with $\mathrm{Fc}$ receptors ${ }^{31}$. It is known, however, that development of antibodies by the patient may establish an "immunologic incompatibility" and the immunoglobulin infusions may cause a paradoxical effect, increasing HIV infection. This occurs with monthly 
transfusions of fresh plasma with high concentration of vasoactive intestinal peptide antibodies (anti-VIP), which has the beneficial effect of increasing CD4 count and reducing the viral load, therefore replacing the intravenous immunoglobulin ${ }^{32}$. In our patients, CMV infection was controlled with ganciclovir, except in some patients in group 1 , in whom the infection was detected later or at autopsy, with no time for an effective administration of the drug. In the other 2 groups, a more strict control of opportunistic infections usually occurred. Because the same drug for the treatment of heart failure was used in the 3 groups, the control of HIV viral load and of the associated infections may explain the lower number of cardiac complications.

In conclusion, the patients receiving only zidovudine as an antiretroviral agent usually had a higher incidence of clinical complications and worse evolution of the cardiac manifestations as compared with the most recent patients, who received combinations of drugs.

\section{References}

1. Brasil, Ministério da Saúde, Divisão de DST/AIDS. AIDS. Boletim Epidemiológico, ano XI, $\mathrm{n}^{\circ} 3$, junho a agosto de 1998.

2. Herdy GVH, Leite MM, Lopes VGS, Pinto CAM. Alterações cardíacas em crianças com SIDA. Arq Bras Cardiol 1997; 68: 274-7.

3. Connor E, Spering RS, Geller R, et al. Reduction of maternal-infant transmission of HIV-1 with zidovudine treatment. N Eng J Med 1994; 331: 1173-9.

4. Center for Disease Control and Prevention (CDC). Guidelines for the use of antiretroviral agents in pediatric HIV infection. MMWR 1998; 47 (RR4): 1-31.

5. Lambert LS, Moye J. Current issues in the immunoprophylaxis of vertical transmission of HIV. BioDrugs 1999; 11: 31-41.

6. Lipshult SE, Easley MS, Orav J, et al. Cardiac dysfunction and mortality in HIV infected children. The prospective P2 C2 HIV multicenter study. Circulation 2000; 102: 1542-8.

7. Brasil, Ministério da Saúde, Divisão de DST/AIDS. AIDS consenso sobre terapia anti-retroviral para crianças infectadas pelo HIV. 2001; ano XIII: 1-33.

8. Center for Disease Control and Prevention (CDC). Revised classification system of human immunodeficiency virus infection in children less than 13 years of age. MMWR 1994; 43 (RR12): 1-10.

9. Feigenbaum H. Echocardiography. In: Braunwald Heart Disease. Chap $3.5^{\text {th }} \mathrm{ed}$. Philadelphia. WB Saunders Co, 1997: 53-98.

10. Nogueira G, Macedo AJ, Paixão A, et al. Cardiovascular morbidity in children with HIV infections. Acta Med Port 1998; 11: 1051-7.

11. Langston C, Cooper ER, Goldfarb J, et al. HIV related mortality in infants and children: data from the pediatrics pulmonary and cardiovascular complications of vertically transmitted HIV (P2 C2) study. Pediatrics 2001: 107: 328-38.

12. Mofenson LM. Epidemiology and determinants of vertical HIV transmission. Sem Ped Infect Dis 1994; 5: 252-65.

13. Abrams E, Steketee RW. Association of HIV load early in life with disease progress on among HIV infected infants. J Infec Dis 1998; 178: 101-8.

14. American Academy of Pediatrics. Disclosure of illness status to children and adolescents with HIV infection. Pediatrics 1999; 103; 64-6.

15. Lipshultz S, Fox C, Perez Atayde A. Identification of HIV-1 RNA and DNA in the heart and congenital AIDS. Am J Cardiol 1990; 66: 248-501.

16. Domanski MJ, Sloas MM, Follman DA, et al. Effect of zidovudine and didanosine treatment on heart function in children infected with HIV. Paediatrics 1995; 127 : 137-46.

17. Barbaro G. Cardiovascular manifestations of HIV infection. JRS Medicine 2001; 94: 384-90.
18. Beck MA, Kolbeck AC, Shi Q, et al. Increased virulence of a human enterovirus (Coxsackie B3) in selenium-deficiency mice. J Infect Dis 1994; 170: 351-7.

19. Kaul S, Fishbeim MC, Siegel R. Cardiac manifestations of AIDS. A 1991 update. Am Heart J 1991; 122: 535-44.

20. Herdy GVH, Ramos R, Bazin AR, et al. Correlação clínico-patológica de 50 casos de SIDA. Estudo retrospectivo. Arq Bras Cardiol 1994; 60: 95-8.

21. Herdy GVH, Carvalho R, Vasconcelos MC, Ramos RG. AIDS e Coração. In: Celmo Celeno Porto. Doenças do Coração. Cap. 206. $1^{\text {a }}$ Ed. Rio de Janeiro: Guanabara, 1998: 982-5.

22. Parrillo JE, Parker MM, Natanson C, et al. Septic shock in humans. Ann Intern Med 1990; 113: 227-42.

23. Ognibene FP, Parker MM, Natanson C, et al. Depressed left ventricular performance: response to volume infunsion in patients with sepsis. Chest 1998; 93: 903-10.

24. Barbaro G, Di Lorenzo G, Grisorio B, Barbarini G and Gruppo italiano per lo studio cardiológico dei pazienti affeti da AIDS investigators. Cardiac involvement in the AIDS. A multicenter clinical-pathological study. AIDS Res Hum Retroviruses. 1998; 14: 1071-7.

25. Barbaro G, Di Lorenzo G, Soldini M, et al. The intensity of myocardial expression of inducible nitric oxide synthesis influences the course of human immunoficiency virus associated. cardiomyopathy. Circulation 1999; 199: 633-9.

26. Rerkpattanapipat P, Jacobs LE, Kotler MN. Cardiac manifestations of AIDS. Arch Int Med 2000; 160: 602-8.

27. Butler K. Pediatric human immunodeficiency virus infection. In: "GorbachBatlet-Blacklow Infectious Diseases. Cap 140. Saunders Co: Philadelphia, 1992: 1005-20.

28. Valentine M, Jackson C, Vavro C, et al. Evaluation of surrogate and clinical outcome in two years follow-up of 86 HIV pediatric patients. Ped J Infect Dis 1998; 17: 18-23.

29. Shearer WT, Quinn TC, Larussa P, et al. Viral load and disease progression in infants infected with HIV type 1. N Engl J Med 1997; 336: 1337-42.

30. Gullestad L, Aass H, Fjeld JG, et al. Immunomodulating therapy with intravenous immunoglobulin in patients with chronic heart failure. Circulation 2001; 103: $220-5$.

31. Karpas K, Hill M, Youle M. Polymerase chain reaction evidence for HIV-1 neutralization by passive immunization in patients with AIDS. Proc Natl Acad Sci USA 1990; 87: 7613-7.

32. Vejkovic V, Metlas R, Jevtovic D, et al. The role of passive immunization in HIV positive patients. Chest 2001; 120: 661-6. 